(I) To find the length of light wave for which electrolytes are opaque.

(2) To find the rapidity of electrical vibration for which the electrolytes cease to conduct.

With reference to (2), Prof. J. J. Thomson says electrolytes still conduct when the rapidity of alternation is 300 millions per second.

(d) The only immediate effect of the passage of the current upon the body of a homogeneous electrolyte is to alter the temperature, and the alteration of temperature takes place in accordance with Joule's law.

Full references to the literature of the subject are given in the Report.

Report of the Committee appointed to make a digest of the Observations on Mioration of Birds at Lighthouses and Lightvessels which have been carried on diring the past nine year's by the Migrations Committee of the British Association. MTr. Fohn Cordeaux, Secretary. - The Committee have to report that one of their number, Mr. W. Eagle Clarke, of the Museum of Science and Art at Edinburgh, has, with the approbation of the Comnittee, undertaken to prepare the digest of the observations; and all the materials for making the same, including I 500 skeleton maps of the British Islands, provided for the purpose, have accordingly been placed in his hands. The labour of reducing the observations, to show in a concise form and on strictly scientific lines the results of the investigation which was carried on from 1879 to 1887 inclusive, will be easily understood to be enormous; and when it is borne in mind that this heavy work can only be carried on after official hours, your Committee feel that no apology is necessary for the non-completion of the digest this year.

Report of the Committee appointed to arrange an Investigation of the Seasonal Variations of Temperature in Lakes, Rivers, and Esuaries in various parts of the United Kingdon in co-operation with the Local Societies refresented on the Association. Dr. H. R. Mills, Secretary. - It is inadvisable to attempt at present to summarize the results of observations made, as although more than a year's observations are available on some rivers, it is only a few months since the work has been begun on others. At the end of another year it is expected that sufficient data will be found to justify a comprehensive report on the subject. Several members of the Committee have taken much tronble in collecting observations. Dr. Sorby has been good enough to collect and discuss a great mass of temperature observations which he had made from his yacht Glimpse, in the estuaries of the south-east of England during the summer months of five successive years. This will be published separately. Prof. Fitzgerald took charge of the observations in Ireland, where he induced a number of observers to take up the work. Mr. Willis Bund had already inaugurated similar researches on the Severn. Rev. C. J. Steward and Mr. Isaac Roberts rendered important services in their districts. A circular was sent to all the Corresponding Societies in connec tion with the Association, requesting their co-operation, and favourable replies were received from several, intimating that observations had been commenced. The instructions issued to observers are given as an appendix to the present Report.

Report of the Committee on Solar Radiation. - The actinometer devised by the late Prof. Balfour Stewart, for the continuous measurement of solar radiation which was described in the R.epurt of the Association for 188.7 , is now ready for preliminary trials, the internal thermometer with a flat bulb of green glass having been made since the date of that Report. The construcion of this thermometer occasioned a good deal more trouble than had been anticipated. No attempt has at present been made to render the instrument self-recording, as it would cbviously be unwise to incur the outlay which any construction for this purpose would involve, until the result of preliminary trials was such as to encourage a hope that the instrument might really be useful if rendered self-recording.

Report of the Commillee appointed for the purpose of takins steps for the Investigation of the Natural History of the Friendly Islands, or other Groups in the Pacific visited by H. M.S. "Eoeria." Mr. S. F. Harmer, Secretary.-' the Committee have not yet received information which puts them in a position to give any detailed report of the work which is being done in connection with the above subject. The grant has been paid to Mr. J. J.
Lister, who reached Tonga on March I9. After devoting two months to the investigation of the natural history of that group, Mr. Lister joined H.M.S. Egeria, on her arrival at Tonga, with the intention of visiting Samoa, where, by the latest accounts, he was carrying on his researches.

\section{THE AMERICAN ASSOCIATION FOR THE ADVANCEMENT OF SCIENCE.}

THE thirty-eighth annual meeting of this body was held in the fourth week of August at Toronto, Canada. This is the third time in the history of its existence that the meeting-place selected has been on British territory - the first and second being at Montreal in the years 1857 and 1882 .

The arrangements for the entertainment of the visitors were all of that free, open-handed, generous character peculiar to New-World hospitality. A large and representative Local Committee was appointed, and through their instrumentality many facilities for comfort and pleasure were obtained; such for example, as reduced railway fares, the withdrawal of all Customs duties on instruments, specimens, \&c., for use at the meetings, a daily luncheon given gratis at the place of meeting excursions at reduced rates to Niagara, to the Muskoka Lakes, to the Huronian district, and even across the continent to the Pacific coast. There were also the usual number, or perhaps even more than the usual number, of garden parties, evening entertainments, and small excursions to outlying localities of geological, entomological, or botanical interest. Two public lectures were also given, the subject of the first being the evolution of music, of the second, the geological history of Niagara.

Among those present who took an active part in the proceed ings were Prof. James D. Dana; Sir Daniel Wilson, the President of University College, in the Convocation Hall and Lecture Rooms of which the majority of the Sections met; Sir William Dawson, of Montreal ; Dr. Charles C. Abbott ; Prof. N. H. Winchell, of Minneapolis ; Major J. W. Powell, of Washington, the retiring President; T. C. Mendenhali, of Washington, the l'resident for this year; Messrs. Carpmael, Ramsay, Wright, and London, of University College ; Profs. Hall and Newberry, who, with Prof. Dana, were the first three Presidents of the Association; Mr. Macoun ; Dr. T. Sterry Hunt Prof. Alexander Winchell, author of "World Life"; Prof. Heilprin, author of "The Geographical and Geological Distribution of Animals," \&c. ; Messrs. Minot, Morse, Newton, and many others of note. Nor must be omitted the names of Mr. F. W. Putnam, the permanent Secretary; and the following Vice-Presidents of the Association: R. S. Woodward, H. S. Carhart, W. L. Dudley, J. E. Denton, C. A. White, G. L. Goodale, Colonel G. Mallery, and C. S. Hill.

Many sincerely regretted the absence of the learned and genial Professor E. J. Chapman, of University College.

Not much time was wasted at the first meeting in the inevitable speeches and addresses of welcome, and within a couple of hours of the time when the general session was called to order by the venerable Professor Dana, on Wednesday morning, August 28, the various Sections met to organize, preparatory for the delivering in the afternoon of the Vice-Presidential arldresses - the Vice-Presidents of the Association being chosen from, and acting as Presidents of, the several Sections.

The majority of these addresses were of a general or historical character. Mr. Carhart, in the Section of Physics, reviewed the theories of electrical action; Mr. Goodale, in the Biological Section, spoke of protoplasm; in the Department of Anthropology, Colonel Mallery dealt with the somewhat curious and little heard of, though not novel, theory of the Hebrew origin of the Indians of North America, discussirg the arguments in behalf of that theory, especially the very ploblematical ground that the plane of civilization and thought of the Indians of to-day was parallel to that of the Israelites of the Old Testament.

\section{Section of Anthropology.}

A very large number of the papers read in the Section of Anthropology quite naturally referred to the Indians of the American continent. The following is a list of the more important of these :-

The Huron-Iroquois, by Sir Danie] Wilson.

Evidences of the Successors of Palæolithic Man in the Delaware River Valley, by Dr. Charles C. Abbott. 
The Winnipeg Mound Region, by Dr. George Bryce, of the Winnipeg College.

New Linguistic Family in California, by H. Henshaw.

Onodaga Shamanic Masks, by De Cost Smith (Onodaga is a county in the State of New York).

The Phonetic Alphabet of the Winnehago Indians, by Miss Alice C. Fletcher.

The Medawiwin or Grand Medicine Society of the Ojibway, by W. J. Hoffman.

Notes on Aboriginal Fire Making, by Walter Hough.

Aboriginal Mounds of North Dakota, by Henry Montgomery.

The Iroquois White Dog Feast, by Rev. W. M. Beauchamp.

Algonkin Onomatology, by A. F. Chamberlain, of University

College, Toronto.

Government of the Six Nations, by O-ji-ja-tek-ha.

Results of Explorations about the Serpent Mound of Adam

Co., Ohio, for which a grant was made by the Association, by

F. W. Putman.

Aboriginal Monuments of North Dakota, by Henry Montgomery.

Steatite Ornaments from the Susquehanna River, by Atreus Wanner.

Notes on the Eskimo of Cape Prince of Wales, Hudson's Strait, by F. F. Payne, of the Observatory, 'I'oronto.

'The following is a hrief abstract of Sir Daniel Wilson's interestirg paper on the Huron-Iroquois-a branch of a subject in which the writer has for many years conducted important and successful researches :-

The Huron-Iroquois of Eastern Canada.-On the occasion of the first meeting of the American Association for the Advancement of Science in the province of Ontario, it was perhaps a matter of interest to the members of the Anthropological Section to have some special notice of the aborigines of this region to the north of the great lakes. Sir David Wilson accordingly noted that the Indians found in this province on its first occupation by English settlers, as well as those now settled on their reserves in Ontario, are nearly all later intruders than the Anglo-Canadian occupants of the soil. On the Grand River the Six Nation Indians have now been settled for upwards of a century, and have made great progress in civilization. They include the Mohawks, Oneidas, Onondagas, Cayugas, Senecas, and Tuscaroras. But they followed the loyalist british colonists, with whom they had taken part in the War of Independence, and the first of them still preserve the prized heirloom brought with them when they forsook their old native valley of the Mohawk - the silver communion service, inscribed "A.R. 17II. The gift of Her Majesty, Ann, by the Grace of God, of Great Britain, France, and Ireland, and of her plantations. in North America, Queen, to Her Indian Chappel of the Mohawks.' But though the Six Nation Indians have occupied their reserves on the Grand River for little more than a century, they belong to the great Huron-Iroquois stock, of which Canada is the original home. The speaker accordingly gave a detailed account of the first direct knowledge of the Hurons of the St. Lawrence Valley derived from Jacques Cartier's narrative of his two voyages. He first entered the St. Lawrence in 1535 , when he found the palisaded Indian towns of Stadacone and IIoschelaga, on the sites of Quebec and Montreal. We owe to him a vocabulary of their language which proves them to have been Wyandots or Hurons. But when Champlain followed, in 1615 , the whole region was a desert. An account was then given of the Huron settlements visited by Champlain on the Georgian Bay, and their extermination by the Iroquois in 1648 . Next the tradiitions of the race were referred to, all in legendary fashion, embodying the myth of their emerging from the heart of a mountain between Quebec and the Great Sea. Their country thus reached, apparently, to the Labrador frontier, contiguous to the Eskimo country. Skulls of the Hurons and Iroquois were produced, including a cast of that of the famous Mohawk chief, Brant; and attention was drawn to the striking conırast which their predominant dolichocephalic type presented to that of the prevalent American type of skull. In this respect the Huron-Iroquois head-form appruximates to that of the Eskimo, and the special aim of the paper was to show the reasons for believing in an admixture at some remote date of this American stock with the Eskimo, who have been invariably recognized by ethnologists as a distinct type from the true Indian of the northern continent.

The Rev. Mr. Beauchamp's contribution on the Iroquois white dog feast had some points of interest. Among the
Iroquois, the Senecas and Onondagas alone, the u riter showed, seemed to have observed the annual white dog feast, and that only within recent times. It combines some features of both the dream and war feasts, of which it is the successor, and is the beginning of the new year. Penitential exercises take up a portion of the time, with games and various performances of the false faces. His sins confessed and forgiven, his appointed offering made and the fire rekindled on his hearth, the Indian was prepared to enter hopefully on a new year, especially if dreams and games had turned out well. The feast has now lost some of its most striking features, and will very soon altogether pass away.

\section{Section of Geology and Geography.}

The Section of Geology and Geography also devoted much of its time to topics of American interest. Mr. Charles White, in his address as Vice-President, touched on "The Mesozoic Division of the Geological Record as it is exhibited on this Continent," referring more particularly to the principal subdivisions of the Mesozoic that have been recognized in North America, their inter-delimitation, their division as a whole from the Carboniferous system beneath and the Cænozoic above. He held that the Mesozoic strata of the Atlantic coast region consist of a probable representation of the Upper Trias of Europe, a possible one of the Upper Jura, a probable slight one of the Middle Cretaceous, but with a hiatus between the latter and the Eocene.

Another paper in this Section, dealing in comparisons of Cis- with Trans-Atlantic formations, was that of Prof. IH. S. Williams, of Cornell University, Ithaca. He gave an account of his examination of the English Devonian rocks, under the leadership of Messrs. Ussher and Townshend Hall, during the visit of the International Congress of Geologists in 1888 . Comparison of the rocks and fossils with those of Eastern North America led to the conclusions $(a)$ that the fossils are very closely allied to the species of the New York Devonian, although in the great majority of cases passing under different names ; and (b) that the rocks, in their appearanc $=$, composition, and order, are as different as two distinct systems well can be. The great Devon limestone of South Devonshire and Cornwall furnished the fossils upon which Lonsdale based his conclusion that the fauna was intermediate between the fossils of Murchison's Silurian system and those of the Carboniferous limestone, which led to the establishment of a "Devonian" system. When other European localities had furnished more perfect sections of this system, the fauna of this limestone was recognized as the Middle Devonian fauna, and that of Marwood, Pilton, Sloly, \&c., as an Upper Devonian fauna. But neither the order of sequence of the rocks nor the separation of the fossils into welldefined faunas can be satisfactorily determined by study of these Devonian rocks alone. Although they have furnished geological nomenclature with a name for the system, they are far from being typical of the Devonian system, as known to most geologists. Comparison of the faunas of the European Devonian faumas with those of the Appalachian basin leads to the hypothesis that the marine life of the two areas had different histories. There is a continuity in the succession from lowest to highest zones of the system in Europe which we do not find in the American series. It is evident that the American Lower and Middle Devonian faunas are more distinct from the corresponding faunas of Europe than are the "cuboides" and later Devonian faunas of the two areas. To account for these facts it is conjectured that a barrier separated the two districts during the lower and middle stages of the Devonian, and that with the "cuboides" stage an incursion of European species began from the European area westward or north-westward, penetrating the Appalachian basin. The mingling of species was not complete, and was stopped altogether by the elevation which terminated the marine Chemung fauna of the New York area. The author also found evidence for the belief that the early Carboniferous faunas advanced northward in the central and Appalachian basins to take the place of the Hamilton and Chemung faunas, which in large measure ceased.

Mr. Frank Leverett, of the U.S. Geological Survey, read a paper on the glacial phenomena of North-Eastern Illinois and Northern Indiana. The paper opens with an explanation of the methods of study already employed, and other methods to be employed in deciphering the history of the drift. A brief discussion is given of the features and phenomena included under the term moraine as restricted in the paper. Among these 
features, knobs and basins, swells and says, smooth ridges of till and boulder belts, may be included (though such topography and features are under some conditions non-morainic), but the till plain, "or ground moraine," is not included.

The moraines here discussed are terminal to the ice but not to the drift-covered portions of these States. Four evidences of advances in the production of later moraines are cited:( 1 ) buried soils in sitz between till sheets; (2) changes of direction in flow as shown by striæ ; (3) change in form of ice-lobe as indicated by the distribution of the moraine belts and shiftings of the re-entrant and lobate portions; (4) evidence of push or advance in the moraine itself.

The number of distinct moraines varies because of partial coalescence or of local obliteration of portions of certain moraines by later advances. For this reason correlation is difficult. Aside from the difficulty cited there is an increase in the complexity in passing from older to newer moraines. In the older ones the interlobate portions are short, and the moraines can be traced around continuously from one lobe to another through the re-entrant portions. But in newer moraines the terminal loops meet on opposite sides of large interlobate moraines, and correlation is made only after critical study of their connections, over-riding, overwash, \&c.

Suggestions are made upon the subject of progressive lobation, but caution is urged against advancing general schemes too early. The study has not been carried far enough to make it possible to draw conclusions of that high order to which future extension of the work will lead.

Before the leading time-intervals in this district can be properly outlined, wider correlations must be made and erosion studies must be carefully prosecuted by competent investiga tors of erosion phenomena.

\section{Section of Economic Science and Statistics.}

Not the least interesting of the papers of this Section was one on "Food Moulds the Race," by Mrs. Nellie S. Kedzie, of the Department of Household Economy and Hygiene in the Kansas State Agricultural College. Mrs. Kedzie traced Irish discontent to the fact that, as she states, whereas "the population of England talic on an average $4^{\frac{1}{2}}$ lbs. of meat per day," the Irishman eats but $2 \frac{1}{2}$ oz. per week. "A hungry man is an angry man," Mrs. Kedzie affirmed, and added, "What wonder that the Irish have grown rebellious, suspicious, and lawless " !

A more serious and imporiant paper in this Section was that of Mr. F. Lester Ward on "The Sociological Position of Protection and Free Trade." The author advocated a protective tariff, and his arguments may be briefly summed up thus :-A protective tariff is a means employed by the State to encourage activities beneficial to that State. The principle is that of inducing certain individuals to put forth energies resulting in benefit to the community at large. Against the argument that publir. money should not thus be given to private individuals, Mr. Ward urged that the public funds thus spent were analogous to the moneys spent in salaries to Government officials-the end was the same in both cases, viz. the public welfare. A protective tariff tended to make the State self-sustaining. The statesman is not a humanitarian; his duty is the weal of his own country. He is justified, therefore, in advocating measures of self-defence. But as with individuals, so with States: those acts which are performed for the object of self-defence conduce to the welfare of the collective whole. There is no such thing as free competition. The term itself implies friction. It requires intelligent interference to preserve competition free. Competition left to itself promotes monopolies. The protective tariff prohibits the unnecessary transportation of commodities. This results in economy.

But the paper that altracted the largest amount of attention in this Section was that of Mr. R. L. Fernow, chief of the Forestry Division of the Department of Agriculture of the United States. A graduate of a Forestry Academy of his own country, Germany, where, as he himself said, the preservation of fore:ts is traditional, Mr. Fernow is astonished at the carelessin many cases, indeed, deliberate-wastefulness with which the New World utilizes its treasures of timber, and he looks to the "Government to remedy the evil. "As far as the forest yields material for the arts," he said, "it is an object of private industry; but when, by its position on a watershed, the forest becomes an influential factor in the water conditions of the plain, it may still serve the purpcses of gain and wealth, which are the objects of private industry, but its indirect significance for society at large exceeds the private interest, and this class of resources, being in the direction of a social gain or gain for a larger number, must become an object of public economy by the State or community."

The following passage from Mr. Fernow's paper is worthy of quotation, showing as it does his perspicacious views on this difficult problem of forest conservation :-

"Whatever tends to stimulate private activity is to be promoted. Whatever retards development of intensive methods is to be removed by Government. Industrial education, cultural surveys, organization of national irrigation systems, fish commissions, bureaus of information, experimental stations and other aids to private enterprise will constitute the chief methods of expressing State interest with regard to these resources. The three great sources upon which mankind is most clependent, which demand first the attention of the State, are the soil, as food producer, the water, and climatic conditions. A rational management of the water capital of the world in connection with the agricultural use of the soil will become the economic problem of the highest importance, as the necessity for increased fnod production calls for intensive methods. In the United States the action of the Government on economic and cultural questions is apt to be fitful and the result of per:onal influence rather than a logical analysis of conditions and principles. While our Government is ready to go to war in order to protect its fi:heries, it has never even known the value as food supply of the game which has been killed. Whole races of animals have been extirpated before there were population enough to require the meat. While with one hand we pay exorbitant prices in land and wasted energy to get the plains re-forested, and that with poor success, with the other hand we offer a premium for forest destruction in mountains by leaving them without proper administration. And now we propose to establish irrigation systems, neglecting to provide first for those conditions which assure a regulated water supply-namely, by forest preservation."

This paper led to the adoption by the Association of three resolutions: one, that Congress be memorialized on behalf of a proper administration of the forests of the western mountain ranges; a second, that legislative enactments were necessary for the development of natural resources; and a third, appointing a committee to urge the importance of these matters on the President and Congress of the United States and on the Premier and Parliament of Canada.

\section{Section of Chemistry.}

The Vice-Presidential address in this Section was read by Prof. William L. Dudley, of Vanderbilt University, who gave a résumé of the more important researches on the nature of amalgams, to which was appended a very complete index to the literature on the subject. Prof. Dudley confined himself almost wholly to the historic aspect of his theme, taking occasion only to remark that the results of previous experiments seem to prove that amalgams are chemical compounds more or less unstable.

Mr. Charles Munro spoke on the explosiveness of the celluloids. He gave the results of experiments for testing their stability, flashing-point, \&c., and maintained that the opaque varieties were insensitive to detonation at ordinary temperatures, but that the translucent readily exploded.

Mr. John W. Langley, of I'ittsburg, read a paper on "International Standards for the Analysis of Iron and Steel." He stated that a system of international standards had been arranged for between England, France, Germany, Sweden, and the United States. He gave a description of the system, and asked the Section to name one chemist to act with six others to conduct the analysis on behalf of the American Comnittee on the International Standards, and to co-operate regarding the same with European analysts. The meeting appointed Mr. Thomas M. Brown, of Boston, with Prof. F. A. Gooch, of Yale College, New Haven, Conn., as alternative.

\section{Section of Mathematics and Astronomy.}

In the Section of Mathematics a paper-which resulted in an important resolution being adopted by the Association at large - was read on the Peruvian arc. The two meridional arcs, the one in Peru and the other in Lapland, measured a century and a half ago, were examined by Mr. E. D. Preston, of the United States Coast and Geodetic Survey, with reference to the degree of accuracy attained, and a comparison was made between the 
uncertainties of these measures and those resulting from work with modern instruments, and following more recent methods. It was shown that the probable errors were much larger than would be indicated by the agreement of the published results, and that therefore the concordance of this arc with those in other parts of the world is no proof of its accuracy. By far the most significant errors came from the astronomical observations, and the unavoidable uncertainties here, either from the imperfection of the instruments, or the attraction of the high mcuntains, were shown to affect perceptibly the present value of the earth's axis.

The resolution touching this matter, which was unanimously adopted at a general session of the Association, reads as follows :-

"Whereas the history of geodesy inclucles no more important page than that relating to the measurement in 1739 of the socalled Peruvian arc, which work was conducted by the French Government with the co-operation of Spanish officers, and in magnitude of plan and difficulty of a most serious character it was in its time unexcelled; whereas recent improvements in all the processes incidental to such an undertaking have been so very great, rendering possible a vastly more accurate execution of the work; wherea; it is and has been for several years a matter of deep regret that the one great contribution which the American continent has made to the solution of the problem of the figure of the earth should fall so short of what it should and might : be it therefore resolved by the American Association for the Advancement of Science, that the Congress of the Three Americas about to assemble in Washington is earnestly requested to consider the desirability of urdertaling the measurement of this Peruvian arc, to be accomplished by a union of the Republics represented. This result is not likely to be reached except through international effort, and this recommendation by the Congress would be a fitting and proper act of this first conference of representatives of the New World."

\section{Section of Physics.}

The President of the Association, Mr. T. C. Mendenhall, read before the members of this Section a short paper on globular lightning. He arlduced no new theory as to its source or character, but submitted an interesting account of several authentic records of its occurrence, many of them abstracted from the reports sent in to the United States Hydrographic Office. He showed that there was abundant trustworthy proof that atmospheric electricity took on the form of globular lightning, but conceded that the evidence was in details discordant. He hoped that some day opportunity might be given to obtain a photograph of the phenomenon.

Mr. Thomas Gray read a faper on the relative values of the magnetic and the electrodynamic methods of measuring electric currents in absolute measu es.

In the subsequent disctission on the paper, Prof. Nichols, of Cornell Univer.ity, stated that he had compared the constants of one of Sir William Thomson's balances as certified by him, with the constants as determined by the large standard galvano. meter in Cornell University, and found them to agree perfectly through the entire range-a result with which he was greatly pleased.

Prof. H. S. Carhart, of the University of Michigan, read two papers before this Section, one on magnetic leakage in dynamos, the other on an improved standard cell with low temperature coefficient. The following abstracts of these papers will show their gist and purport :-

The first paper gives an account of some experiments to determine the marnelic leakage of two dynamos of the Mather and Edison type respectively; the former was a small machine of 500 watts capacity, built by a student in the laboratory, the latter an Edison of 5000 watts capacity:

In the small machine the leakage was due to some projecting machine steel studs which carried the armature yokes. The number of magnetic lines cut by the armature when the machine was coupled as a self-exciting shunt dynamo was determined, and then the steel studs were replaced by brass and the determinations were repeated. The result was 190,000 and 252,000 lines of force respectively, or a gain due to removing the steel studs of $32^{2} .6$ per cent. This was partly due, however, to increase in the field when the leakage was stopped. Hence the machine was independently excited by a storage battery, and the number of lines determined in the two cases as before. The result was 164,600 and 184 , 100 lines cut by the armature with and without steel stude, a gain of II'2 per cent. This measured the true leakare due to the assigned cause.

The leakage in the Edison machine was due to the iron bedplate. A plank base was made, and the numter of magnetic lines cut by the armature was determined first with the iron base and then with the plank, the machine being self-exciting and running at the same speed in the two cases. The numter of lines was $I, 5$ ro, 000 and $1,605,000$, a gain of 6.25 per cent. due to removal of the cause of leakage.

In his second paper, on an improred Clark standard cell with low temperature coefficient, Prof. H. S. Carhart said :- "The objections to the Clark cell, as described by Lord Rayleigh, are high and variable temperature coefficient, objectionable mechanical construction, and serious local chemical action. These $I$ have, at least in large measure, overcome. The cell which I now make is so constructed that the mercury cannot reach the zinc during transportation. The temperature coefficient is represented by the equation

$$
\mathrm{E}^{1}-\mathrm{E}\left[\mathrm{I}-000387(t-\mathrm{r} 5)+\cdot 0000005(t-15)^{2}\right] .
$$

Per degree the coefficient is

$$
\text { - }{ }^{\circ} 000386+{ }^{\circ} 00000 \mathrm{r}\left(t-\mathrm{r}_{5}\right) .
$$

At $0^{\circ} \mathrm{C}$. this coefficient becomes - $\mathrm{CcO} 40 \mathrm{O}$; at $25^{\circ},-{ }^{\circ} \mathrm{COO} 376$ and at the highest temperature observed, $52^{\circ} 7$, it is - $\cos 348$. It wi!l be observed that this coefficient diminishes with rise of temperature, while that of Lord Rayleigh's cells increases. In cells of the old form local action is due to zinc replacing mercury when in contact with the solid mercury salt. The zinc is thus amalgamated, and the amalgam creeps up. This I prevent by keeping the zinc out of contact with the mercury salt. The same device has the effect of raising the E.M.F. about 04 per cent. The polarization of these cells amounts to only one ten-thousandth part in five minutes with an external resistance of $\mathrm{IO}, 000 \mathrm{ohms}$. It recorers in a $\mathrm{ft} w$ minutes. The different cells show great uniformity of E.M.F. All comparisons are made by Lord Rayleigh's method slightly modified. A change or difference of E.M.F. of one ten-thousandth part is rery readily detected."

In this Section Messrs. W. A. Rogers and R. T. Woodward, in a paper on mercurial thermometers, held the following theses:-(I) The movements of a mercurial column are in all cases by pulsation ; (2) these pulsations have a regular recurrence; (3) the period of recurrence is constant in the same thermometer; (4) every pulsation has the same harmonic relation: (5) the amplitude of the curve which represerts the harmonic is inconstant ; $(6)$ as the period is constant and the time required for the completion of the cycle variable, it follows that the danger of error in random readings of the thermometer is greater for slow than for rapid variations of temperature.

\section{Section of Biology.}

In the Biological Section, Mr. A. J. Cook read an interesting paper on the alimentary apparatus of the bee, in which he embodied the results of a long series of personally conducted experiments. He differed, he said, widely in many particulars from the author of the article on the anatomy of the bce in the "Encyclopædia Britannica," notably as regards the conformation of the tongue. This organ, Mr. Cook strongly maintained, was a hollow cylinder furnished on the under side with a slit throughout its entire length. He explained that suction could be performed in three ways : (I) through the terminal aperture of the internal tube, when the nectar could be reached only by the end of the tongue; $(2)$ through the slit opening into this tube, when the fluid to be sucked in was shallow and placed on a flat surface; (3) by the aid of the labial palpo when the fluid was abundant. The author also expressed his incredulity as to the possibility of a trustworthy analysis of honey, arguing that in many cases more nectar was taken into the honey-stomach by the bee than the glands had time or secretion sufficient to digest. Especially, he thought, did this happen when the linden was in bloom, when a single hive of bees would sometimes store up I $_{5}$ pounds of honey in the day. The queen bees and the drones, he held, were fed with digested food only, and to this fact he traced the extraordinary fecundity of the queen bee.

Prof. Burrill read a paper on fermentation of ensilage. $\mathrm{He}$ stated that all fermentation of organic matter is now universally admitted to be due to the action of micro-organisms, and he described the phenomena presented in recently stored green fodder, used for cattle food. This material is now placed in 
bins of large size, where it soon becomes very hot, reaching a temperature of $60^{\circ} \mathrm{C}$. $\left(\mathbf{I} 40^{\circ} \mathrm{F}\right.$.). This temperature was sufficiently high to kill or at least prevent the growth of nearly all animal and vegetable species, $50^{\circ} \mathrm{C}$. being the upper limit. Upon the proper examination of this hot material one soon finds that a single species of Bacteria (Bacillus butyricum) is associated with the fermentation and subsequent rise in temperature. Further tests prove that it is the cause of these changes. Secondary changes are very liable to occur as the heat decreases, and lactic and acetic acid, the latter often in large amounts, are produced. Possibly alcohol is sometimes, but never as a first product of the hot material.

On the whole, this the thirty-eighth annual meeting of the American Association for the Advancement of Science may be considered to have been a successful one. Close upon two hundred paper's were actually read in the various Sections, some of these of course not reflecting that "dry light" which is supposed to beat upon all scientific investigation, yet the majority of them cvincing real and enthusiastic work on prop:r lines. One thing however, might have been noticeable to an Enolish ear, many of the writers seemed to possess a greater mastery over abstruseness of subject than over elegance of dicrion.

Many eminent men, some famous in both hemispheres, were present. The total number of persons in attendance on the ineetings, and actually belonging to the Association, either as Fellows, Members, or Associates, was between four and five hundred.

Financially, the Association is declared to be in a better position to-day than ever it has been before. The annual income is at present about $\$ 6000$. It has also the sum of $\$ 4500$ invested at 5 per cent., the interest of which is devoted to the furtherance of original research. For the ensuing year this sum has been apportioned thus: $\$ 150$ to Prof. Moseley to continue his re searches on the velocity of light in the marnetic field; and $\$ 50$ to Prof. Attwater for the purpose of investigating the heats of combustion of certain mineral and vegetable compound;

Indianapolis and the third Wednesday in August were chosen as the place and time of meeting for I890. Mr. G. L. Goodale, of Cambridge, Massachusetts, was elected President for the coming year.

The meeting was closed by a public gathering, at which many complimentary speeches were made both by hosts and guests. Arnold Haultain.

\section{THE IRON AND STEEL INSTITUTE.}

THE autumn meeting of the Iron and Steel Institute was held last week in Paris under the presidency of Sir James Kitson. The meeting was held in the rooms of the Sociéte d'Encouragement, and was addressed, in the first instance, by M. Eiffel, President of the Sociéte des Ingénieurs Civils, and by M. H. de la Goupillière, President of the Société d'Encourage. ment. The President of the Institute, after thanking M. Eiffel and M. de la Goupillière for their kind hospitality, announced that the Council had awarded the Bessemer Medal to M. Henri Schneider, of Creusot, for his services to the iron and steel trade of France, to whom it was presented on Friday by Sir Lowthian Bell. Sir James Kitson made a brief address, referring to their last visit to Paris in 1878 , under the distinguished presidency of the late Sir William Siemens, to the increase in the roll register of the Institute which had taken place since that date. He drew attention to the improvements which had taken place during the last decade in the metallurgy of steel and iron; the commercial development of the Siemens-Martin and Thomas-Gilchrist steel processes; the increased development in the manufacture of steel owing to the extension which had taken place in its applications. The Eiffel Tower was an elegant example of the scientific power and imaginative genius of French engineering, whilst the French chemical study of the processes of metallurgy had rendered great service, not only to their own industry, but to that of the world at large. The names of many eminent French metallurgists were mentioned, and the work they had done was briefly referred to.

The business of the meeting was then proceeded with, viz. the reading and discussion of the various papers which are referred to below.

Prof. S. Jordan's paper, "Notes on Iron and Steel Manufacture in France in 1887 , and as illustrated by the French exhibits at Paris," the first paper read, was of a statistical ciaracter, and compared the present production of these metals with what it was ten years ago.

The Channel Bridge. - This was a paper hy Messrs. Schneider and Co., of Creusot, and M. H. Hersent, Past-President of the Société des Ingénieurs Civils, descriptive of a bridge for connecting England with the Continent. The paper consists of three parts, an introductory notice, a general description of the bridge, and of the superstructure, being preliminary projects of M. Hersent and Messrs. Schneider respectively. From the introductory notice it would appear. that projects have been submitted by Messrs. Fowler and Baker, but these are not published in the paper.

It is proposed that the bridge should span the Channel at about its narrowest portion-namely, between Folkestone and Cape Griznez, a distance of 25 miles, by which means also the sand-banks of Varne and Colbart can be taken advantage of, thereby diminishing the height of the piers necessary to be erected. These banks are in mid-Channel, about $3^{\frac{3}{4}}$ miles apart, and are separated by a depression of between 80 and 90 feet deep ; this is also about the depth between the bank and the British coast, whilst on the French side, between the Colbart Bank and the Cran-aux-Cufs, the bottom siniks somewhat abruptly down to I 32 feet, at taining I 80 feet about midway across, when it gradually rises again. In these parts the chief difficulties would be encountered in laying the foundations. As the result of frequent experiments, it is found that the blue and white chalk which forms the Channel bottom is capable of supporting a load of from I 40 to I 70 pounds to the square inch, and the surface of the bases of the piers has been so calculated that the forndations should not have a greater load on them than the smaller of these amounts. This would imply that no factor of safety has been allowed, which is hardly likely to be the case, as in masonry structures with a live load a factor of safety of 8 is generally recommended; on the other hand, the ordinary kinds of chalk are capable of resisting a crushing pressure of 330 pounds per square inch. The masonry piers are 190 feet in length at the base, and I 40 feet above, the width depending on the columns which they have to support. The distance between the piers is fixed at I650 and 990 feet, II55 and 660 feet, and 825 and 330 feet, the largest spans corresponding to the greatest depths, and the smaller ones to smaller depths and the parts near the shore. Each supporting pier will consist of a block of masonry of best material, set with Portland cement, and laid on the sea bottom ; the masonry will be built inside metal caissons similar to those used for ordinary bridge piers, and forced by compressed air down to the solid ground. Their surface above high-water Jevel will form the foundation for the metal columns, which are cylindrical in shape, and vary in height between I 32 and I 40 feet, and on them are placed the main girders of the bridge. These girders are 200 feet above low-, and I 78 feet above high-water level. This height is amply sufficient for the passage of the largest ships. The system of girders proposed to be employed is simple, unlatticed, trussed, so as to insure the proper distribution of all the stresses. After consideration it has been found advisable, instead of forming the 990 and 1650 feet spans of girders extending over the whole length of 990 feet, and extending on either side in the form of cantilevers of 825 feet, so that the junction of the two cantilevers should constitute a span of 1650 feet in all, not completely to cover the spans by means of cantilevers, but to connect these by an ordinary independent span, a saving of $I 7$ per cent. being thus realized in each overhanging portion of the cantilever. In this manner the I650-feet span comprises two cantilevers of 6 19 feet each, and an independent span of 412 feet. The metal flooring on the central span and cantilever is formed of two girders resting upon two piers 990 feet apart, and lengthened on either side to the extent of 6 I9 feet. These girders are 36 feet high at the ends of the overhanging portions, and $2 \mathrm{r} 4 \mathrm{feet}$ high almost throughout the span of 990 feet. Each girder consists of two chords connected by bracings forming isosceles triangles. The lower ribs of the two girders have a distance of 82 feet between their axes in the central span of 990 feet, and an interval of 33 feet at the ends. The level of the permanent way is 237 feet above low water; a double set of rails is proposed, and the width of flooring proper will be 26 feet.

The paper further gives a detailed description of the foundation work, comprising the situation and dimensions of the piers, the construction, conveyance, and fitting into position of the supporting columns, and the materials and machinery required for the com. pletion of the work ; also the construction, transport, and putting 